\title{
NILAI-NILAI PENDIDIKAN DALAM SURAT LUQMAN
}

\author{
Mukodi \\ STKIP PGRI Pacitan \\ e-mail:mukodi@yahoo.com
}

\begin{abstract}
The result of this study - library research - showed that the values of Islamic education are contained in the Holy Qur'an surah Luqman verses 12-19. There are at least three basic education, namely aqidah education, syari'ah education and character education. Aqidah education, there are two things: (1) prohibition of associating partners with Allah. Luqman al-Hakim himself had to prioritize monotheism education (tauhid) to his children, (2) believe in the place of hereafter. Luqman ordered his children to believe the reward of all his deeds. Especially retaliation for our gratitude to Him for every blessing and our sense of respect for both parents. Syariah Education, there are two things, namely a command set up prayer and amar ma'rüf nahy munkar. Character education, which is the command to ingratitude towards Allah SWT. For all the blessings and grace of God, we should be grateful to Him.
\end{abstract}

Artikel ini merupakan penelitian kepustakaan. Penelitian menunjukkan bahwa pendidikan Islam termuat dalam al-Qur'an Surat Lukman 12-19. Setidaknya ada tiga tingkatan yaitu pendidikan aqidah, pendidikan syari'ah, dan pendidikan karakter. Pendidikan aqidah meliputi dua hal: (1) larangan mensekutukan Allah. Lukman Hakim memprioritaskan pendidikan tauhid kepada anak-anak; (2)mempercayai hari akhir. Lukman Hakim mengajarkan kepada anak-anaknya untuk mempercayai balasan atas perbuatan yang dilakukan di dunia. Pendidikan syariah meliputi dua hal, yaitu mendirikan sholat dan amar ma'rüf nahy munkar. Pendidikan karakter meliputi perintah untuk bersyukur kepada Allah atas semua karunia-Nya.

Keywords: Luqman al-Hakim, pendidikan aqidah, pendidikan syariah, pendidikan akhlak 


\section{A. Pendahuluan}

Tujuan pendidikan Islam, tidaklah sekedar proses alih budaya atau ilmu pengetahuan (transfer of knowledge) tetapi juga proses alih nilai-nilai ajaran Islam (transfer of islamic values). Tujuan pendidikan Islam pada hakikatnya menjadikan manusia yang bertaqwa, manusia yang dapat mencapai al-falāh, serta kesuksesan hidup yang abadi di dunia dan akhirat (muflihūn). ${ }^{1}$

Al-Qur'an sebagai dasar pokok pendidikan Islam di dalamnya terkandung sumber nilai yang absolut, eksistensinya tidak mengalami penyesuaian sesuai dengan konteks zaman, keadaan dan tempat. Surat Luqman adalah salah-satu surat al-Qur'an yang secara keseluruhan (umum) di dalamnya terangkum aktivitas pendidikan seperti penyadaran fi'l-dīn, menumbuhkan, mengelola dan membentuk wawasan (fikrah), akhlak dan sikap Islam, menggerakkan dan menyadarkan manusia untuk beramal shalih, berdakwah (berjuang) dalam rangka memenuhi tugas kekhalifahan dalam rangka beribadah kepada Allah. ${ }^{2}$ Dalam ayat ke-12 surat Luqman dinyatakan Allah telah mengaruniakan hikmah kepada Luqman, sedangkan ayat 13-19 berisi nasihat-nasihat atau wasiat Luqman terhadap anak.

Berangkat dari itu, di sini penulis mencoba mengontekstualisasikan ayat tersebut dengan kepribadian anak guna menumbuhkan kepribadiannya menjadi pribadi Islami di masa depan. Kepribadian islami (Muslim) adalah kepribadian yang beriman dan bertaqwa, yang menunjukkan pengabdiannya kepada Allah SWT, untuk memperoleh ridha-Nya, sehingga mendapatkan kebahagiaan (keselamatan) dunia dan akhirat. ${ }^{3}$ Karena tidak sedikit orang tua yang melaikan tugasnya untuk memberikan bimbingan dan arahan kepada anak-anaknya sesuai dengan potensi fitrahnya. ${ }^{4}$ Kajian ini nantinya difokuskan pada nilai-nilai pendidikan Islam serta implikasinya yang ada dalam al-Qur'an surat Luqman ayat 12-19 terhadap kepribadian anak.

1 A. Syafi'i Ma'arif, Pendidikan Islam di Indonesia, Antara Cita dan Fakta, (Yogyakarta: Tiara Wacana, 1991), h. 41.

2 Ibid., h. 53.

${ }^{3}$ AhmadD. Marimba, Pengantar FilsafatPendidikan Islam, (Bandung: al-Ma'arif, 1989), h. 78.

4 Ahmad Tafsir, Ilmu Pendidikan dalam Perspektif Islam, (Bandung: Remaja Rosdakarya, 2001), h. 35. 


\section{B. Pendidikan Islam dalam al-Qur'an}

Pendidikan Islam yang dilaksanakan dalam suatu sistem memberikan kemungkinan berprosesnya bagian-bagian menuju ke arah tujuan yang ditetapkan sesuai ajaran Islam. Jalannya proses itu baru bersifat konsisten dan konstan (tetap) bilamana dilandasi dengan pola dasar pendidikan yang mampu menjamin terwujudnya tujuan pendidikan Islam. ${ }^{5}$

Menurut Hamka, kandungan al-Qur'an sebagai dasar ideal pendidikan Islam secara garis besarnya dapat dikelompokkan menjadi tiga kelompok yaitu: pertama, al-Qur'an mengandung hukum-hukum yang berkaitan atau bersangkutan dengan halal-haram, farāiḍ dan wäjibāt (seruan dan perintah yang pasti) baik yang dianjurkan maupun yang dilarang serta hukuman bagi siapa yang melanggarnya. Kedua, al-Qur'an mengandung hal-hal yang bersangkutan dengan 'aqĩdah atau kepercayaan yang dalam bahasa Indonesia dikenal dengan doktrin. Ketiga, al-Qur'an mengandung hal-hal yang bersangkutan dengan kisah-kisah dan cerita-cerita zaman lampau, sebagai pelajaran dan i'tibār. ${ }^{6}$

Kategori kedua dan ketiga tersebut di atas, merupakan kandungan alQur'an surat Luqman ayat 12-19 yang berisi tentang kisah Luqman. Dalam kisah tersebut banyak nilai-nilai pendidikan yang dapat diambil sebagai pelajaran yang masih sangat relevan dan dapat dijadikan rujukan untuk diaplikasikan dalam proses pendidikan dewasa ini, khususnya pendidikan keluarga.

Bila pendidikan kita pandang sebagai suatu proses, maka proses tersebut akan berakhir pada tercapainya tujuan akhir pendidikan. Suatu tujuan yang hendak dicapai oleh pendidikan pada hakikatnya adalah suatu perwujudan dari nilai-nilai yang terbaik dalam pribadi yang diinginkan. Nilainilai ideal itu mempengaruhi dan mewarnai pola pendidikan manusia, sehingga menggejala dalam perilaku lahiriah. Dengan kata lain, perilaku lahiriah adalah cermin yang memproyeksikan nilai-nilai ideal yang telah mengacu di dalam jiwa manusia sebagai produk dari proses kependidikan. ${ }^{7}$

5 Abdurrahman Saleh, Teori-teori Pendidikan Berdasarkan al-Qur'an, terj. H. M. Arifin, (Bandung: Rineka Cipta, 1994), h. 54.

${ }^{6}$ Hamka, Tafsir al-Azhar, Juz XXI, (Surabaya: Yayasan Latimojong, 1991), h 25-29.

${ }^{7}$ Hamka, Tafsir al-Azhar, h. 31. 
Jika berbicara tentang pendidikan Islam, berarti berbicara tentang nilainilai ideal yang bercorak Islam. Hal ini mengandung makna bahwa tujuan pendidikan Islam tidak lain adalah tujuan yang merealisasikan idealitas Islam. Sedangkan idealitas Islam sendiri pada hakikatnya adalah mengandung nilai perilaku manusia yang dijiwai oleh iman dan taqwa kepada Allah sebagai sumber kekuasaan mutlak yang harus ditaati.

Sebagaimana dikemukakan oleh Hasan Langgulung ketika membicarakan pendidikan Islam, menurutnya pendidikan Islam harus mengakomodasikan tiga fungsi atau nilai agama yaitu fungsi spiritual yang berkaitan dengan aqidah dan iman, fungsi psikologis yang berkaitan dengan tingkah laku individual yang termasuk dalam akhlak, yang mampu mengangkat derajat yang lebih sempurna, dan fungsi sosial, yang berkaitan dengan aturan yang menghubungkan manusia lainnya atau masyarakat, dimana masing-masing mempunyai hak-hak dan tanggung jawabnya untuk menyusun masyarakat yang harmonis dan seimbang. ${ }^{8}$

Sejalan dengan pendapat Hasan Langgulung, Jusuf Amir Feisal—sebagaimana dikutip Zuhairi-berpendapat bahwa agama Islam sebagai supra sistem mencakup tiga komponen sistem nilai (norma) yaitu sebagai berikut:

Pertama, norma aqidah atau norma keimanan seperti iman kepada Allah, malaikat, al-Qur'an, rasul, hari kiamat dan taqdir. Kedua, norma syariah yang mencakup norma ibadah dalam arti khusus maupun dalam arti luas (yang menyangkut aspek sosial) seperti: perumusan sistem norma-norma kemasyarakatan; sistem organisasi ekonomi, dan sistem organisasi kekuasaan. Ketiga, norma akhlak, baik yang bersifat vertikal, yaitu hubungan antar manusia dengan Allah, maupun yang bersifat horizontal yaitu tata krama sosial.

Ketiga prinsip sistem nilai ajaran (pendidikan) Islam tersebut, pada hakikatnya terdiri dari aqidah, syariah (ibadah dan muamalah) dan akhlak. Alih kata, ketiga prinsip tersebut disebut "tri tunggal", baik dalam prinsipprinsip dasarnya, maupun dalam prakteknya, semakin kuat keimanan seseorang dan semakin taat seseorang, maka semakin baik pula akhlaknya. Meskipun para ahli masih belum memiliki kesepakatan tentang makna kepribadian secara definitif terhadap jati diri manusia, namun pada umum-

${ }^{8}$ Hasan Langulung, Beberapa Pemikiran Pendidikan Islam, (Bandung: al-Ma'arif, 1980), h. 178. 
nya mereka mengakui bahwa peran pendidikan dan pengalaman religiusitas anak sejak dini akan memegang peran yang sangat penting. ${ }^{9}$

Menurut Koentjaraningrat pola kelakuan setiap manusia secara individual adalah unik dan berbeda dengan manusia lain. Karena itu, para ahli antropologi, sosiologi, dan psikologi yang mempelajari pola-pola kelakuan manusia ini juga tidak lagi berbicara mengenai pola-pola kelakuan atau patterns of behavior dari manusia, melainkan mengenai pola-pola tingka-laku, atau pola-pola tindakan (patterns of action) dari individu manusia. Apabila seorang ahli antropologi, sosiologi, atau psikologi berbicara mengenai "pola kelakuan manusia," maka yang dimaksudkannya adalah kelakuan dalam arti yang sangat khusus, yaitu kelakuan organisme manusia yang ditentukan oleh naluri, dorongan-dorongan, refleks-refleks, atau kelakuan manusia yang tidak lagi dipengaruhi oleh akalnya dan jiwanya, yaitu kelakuan manusia yang membabi-buta. ${ }^{10}$

Lebih lanjut, dijelaskan susunan unsur-unsur akal dan jiwa yang menentukan perbedaan tingkah-laku atau tindakan dari tiap-tiap individu manusia itu, adalah apa yang disebut sebagai "kepribadian" atau personality. Lain halnya dengan Koentjaraningrat, menurut pandangan psikoanalisa Sigmund Freud tentang hakikat pribadi manusia adalah buruk, hanya berupa dorongan-dorongan seksual atau libido seksualitas yang mencari kenikmatan semata, yang terkandung dalam Id. Lebih lanjut menurutnya kepribadian manusia terdiri dari tiga sistem, yaitu: Id (dorongan-dorongan biologis), Ego (kesadaran terhadap realitas kehidupan), dan Super Ego (kesadaran normatif) yang berinteraksi satu sama lain dan masing-masing memiliki fungsi dalam mekanisme yang khas.

Selain ketiga sistem tersebut, Sigmund Freud menjelaskan tentang jiwa manusia dalam tiga strata kesadaran: alam sadar (the conscious), alam pra sadar (the pre concious), dan alam tak sadar (the unconscius) yang secara dinamis berinteraksi satu sama lainnya. Temuan alam tak sadar ini dianggap sebagai karya Sigmund Freud yang orisinil dan monumental.

Pengetahuan Sigmund Freud yang sangat mendalam tentang jiwa manusia menjadikannya pesimistis dan kritis. Ia tidak mempunyai pandang-

\footnotetext{
9 Baca: Zuhairi, dkk, Sejarah Pendidikan Islam, (Jakarta: Depag, 1996).

10 Baca: Koentjaraningrat, Pengantar Ilmu Antropologi, (Jakarta, Rineka Cipta, 2002).
} 
an yang tinggi terhadap bagian terbesar manusia. Menurutnya tenaga-tenaga irrasional (alam tak sadar) dalam jiwa manusia demikian besar dan kuatnya, sehingga tenaga-tenaga rasional (alam sadar) hanya mempunyai kemampuan kecil untuk mengalahkannya. Oleh karena itu, ia melukiskan gunung es di permukaan laut, puncaknya yang kelihatan sebagai bagian-bagian yang sadar merupakan bagian kecil dibandingkan dengan bagian yang tidak sadar. ${ }^{11}$

Psikoanalisis bersifat deterministik dan pesimistik dalam memandang pengembangan diri manusia, Sigmund Freud terlalu menekankan pengaruh pengalaman masa lalu yang menentukan perkembangan menusia. Perkembangan manusia ditentukan oleh pengalaman masa kecilnya terutama pada usia 0.0- 0.5 tahun. Berbeda dengan pandangan psikoanalisa, psikologi humanistik Abraham Maslow sangat optimistik dalam memandang perkembangan manusia. Manusia adalah makhluk yang memiliki potensi yang cukup besar, manusia memiliki otoritas atas kehidupannya sendiri. Asumsi ini menunjukkan bahwa manusia adalah makhluk yang sadar, mandiri, pelaku aktif yang dapat menentukan (hampir) segala perbuatannya.

Nampaknya pandangan psikologi humanistik inilah yang lebih dekat dengan pandangan Islam daripada pandangan psikoanalisa yang jelas-jelas sangat bertentangan. Islam memandang, pada hakikatnya manusia sejak lahir membawa potensi fitrah yang suci dan beriman, manusia pada dasarnya adalah baik. Sebagaimana dijelaskan dalam hadits Nabi:

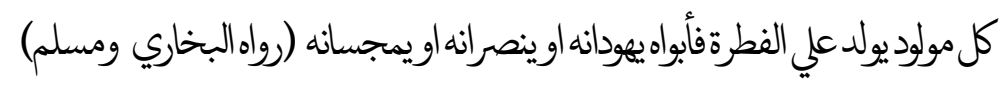

Tiap orang dilahirkan membawa fitrah; ayah dan ibunyalah yang menjadikannya Yahudi, Nasrani, atau Majusi. ${ }^{12}$

Hadits tersebut, menjelaskan bahwa dalam proses perkembangannya manusia dipengaruhi oleh faktor lingkungan disamping faktor bawaan yang berupa potensi fitrah tersebut. Dalam proses perkembangannya manusia sebagai subjek yang membangun dan mengembangkan diri pribadinya sesuai dengan khithah kejadiannya.

11 Calvin S. Hall, Pengantar Kedalaman Ilmu Jiwa Sigmund Freud, penerjemah: S. Tasref, (Yogyakarta: Pembangunan, 1991), h. 26.

12 HR. Bukhari dan Muslim. 
Peletakan tanggung jawab dalam proses penyempurnaan diri pada manusia itu ada dalam al-Qur'an, ${ }^{13}$ sehingga dalam proses penyempurnaan diri itu manusia berdiri sebagai subjek yang sadar dan bebas menentukan jalan kehidupannya sendiri, menentukan pilihannya apakah memilih fujūr (menyimpang dari kecenderungan potensi fitrahnya), atau taqwa (sesuai dengan kecenderungan potensi fitrahnya), masing-masing memiliki resiko sendiri-sendiri.

Penentuan pilihan itulah para orang tua memegang peranan yang sangat penting. dimana mereka berupaya memberikan bimbingan dan arahan kepada anak-anaknya sesuai dengan potensi fitrahnya, sehingga mereka nantinya tumbuh dalam kepribadian Islami. ${ }^{14}$

\section{Mendefinisikan Nilai}

Sebuah laporan yang ditulis oleh A Club of Rome (UNESCO, 1993), nilai diuraikan dalam dua gagasan yang saling bersebrangan. Di satu sisi, nilai dibicarakan sebagai nilai ekonomi yang disandarkan pada nilai produk, kesejahteraan, dan harga,-_dengan penghargaan yang demikian tinggi pada hal yang bersifat material. Sementara di lain hal, nilai digunakan untuk mewakili gagasan atau makna yang abstrak dan tak terukur dengan jelas. Nilai yang abstrak dan sulit diukur itu antara lain keadilan, kejujuran, kebebasan, kedamaian, dan persamaan. Di kemukakan pula, sistem nilai merupakan sekelompok nilai yang saling menguatkan dan tidak terpisahkan. Nilai-nilai itu bersumber dari agama maupun dari tradisi humanistis. Karena itu, perlu dibedakan secara tegas antara nilai sebagai kata benda abstrak dengan cara perolehan nilai sebagai kata kerja. Dalam beberapa hal sebenarnya telah ada kesepakatan umum secara etis mengenai pengertian nilai, walaupun terdapat perbedaan dalam memandang etika perilaku. ${ }^{15}$

Secara falsafati, nilai menurut Rohmat Mulyana ${ }^{16}$ dapat ditinjau dari segi ontologi, epistemologi dan aksiologi. Dalam perspektif ontologi, nilai dikaji dari lingkup hakikat dan struktur nilai. Ditinjau dari perspektif epistemologi;

${ }^{13}$ QS. al-Syams [91]: 8.

${ }^{14}$ Ahmad Tafsir, Ilmu Pendidikan..., h. 35.

${ }^{15}$ Rohmat Mulyana, Mengartikulasikan Pendidikan Nilai, (Bandung: Alfabeta, 2004), h. 8.

16 Ibid, h. 89. 
meliputi objek nilai; cara memperoleh nilai; ukuran kebenaran nilai. Adapun penjelasannya sebagai berikut:

1. Ontologi

a. Hakikat nilai: nilai adalah rujukan dan keyakinan dalam menentukan pilihan.

b. Struktur nilai: (1) berdasarkan patokannya (logis, etis, estetis); (2) berdasarkan klasifikasinya (terminal instrumental, subjektif-objektif, instrinsik-ekstrinsik, persoalan-sosial); (3) berdasarkan kategorinya (empirik, teoritik, etika, politik, sosial, agama); dan (4) berdasarkan hierakinya (kenikmatan, kehidupan, kejiwaan, kerohanian).

2. Epistemologi

a. Objek nilai: (1) ajaran agama dan perilaku religius; (2) logika filsafat dan karakter berfikir filosofis; (3) teori ilmu pengetahuan dan sikap ilmiah; (4) norma (theistik atau humanistis) dan perilaku etis; (5) adat kebiasaan (theistis atau humanistis) dan perilaku taat ada; (6) karya seni (theistik atau humanistis) dan perilaku estetis.

b. Cara memperoleh nilai: (1) memfungsikan otak melalui kontemplasi, berpikir rasional, logis, dan empiris; (2) memfungsikan hati melalui meditasi, tharīqat, atau riyāḍh.

c. Ukuran kebenaran nilai; (1) logik-theistik; (2) logik-humanistik; (3) logik-empirik-theistik; (4) logik-humanistik; (5) mistik-theistik; (6) mistik-humanistik.

3. Aksiologi

a. Kegunaan pengetahuan nilai: (1) nilai pada wilayah filsafat; untuk menentukan cara hidup dalam bermasyarakat dan beragama; (2) nilai pada wilayah ilmu pengetahuan; untuk mencerahkan batin dalam kesadaran beragama.

b. Cara pengetahuan nilai menyelesaikan masalah: (1) nilai pada wilayah filsafat dengan cara menelaah akar permasalahan atas lahirnya nilai (baik-buruk, benar-salah, indah tidak indah; (2) nilai pada wilayah ilmu pengetahuan dengan cara penyadaran, dan lainlain; dan (3) nilai pada wilayah mistik dengan cara wirid; puasa; shalawat dan lain-lain. 
Berpijak pada perspektif tersebut di atas, nilai-nilai pendidikan yang terkandung dalam Surat Luqman tentunya dibangun melalui keseluruhan dari batang tubuh pengetahuan itu sendiri.

\section{Konsep Pendidikan Luqman al-Hakim}

\section{Sosok Luqman al-Hakim}

Bagi sebagian besar kaum Muslimin, nama Luqman al-Hakim tentu sudah cukup familier. Mengingat sering kali para mubalig, ustadz/ustadzah menjadikan dirinya sebagai figur teladan, pola asuh orang tua dalam membimbing anak-anaknya. Tetapi, mungkin ada di antara kita yang bertanya-tanya, apakah ia termasuk Nabi atau memang seorang yang bijak dalam menjalani hidupnya, bahkan mungkinkah ia hanya sekedar bahasa simbol yang ditulis dalam alQur'an bagi orang-orang yang mempunyai kebijakan dalam menjalani tugasnya sebagai khalifah di muka bumi ini. Pendapat-pendapat tersebut memang sampai sekarang masih menjadi diskursus. Di sini, akan saya kemukakan beberapa pendapat para ahli tentang siapa Luqman al-Hakim itu.

\section{a. Menurut Ahmad Musthafa al-Maraghi}

Luqman al-Hakim ialah seorang tukang kayu, kulitnya hitam dan termasuk penduduk Mesir yang hidup serba sederhana. Namun demikian, Allah SWT telah memberikannya hikmah dan menganugerahkan kenabian kepadanya. ${ }^{17}$

Pendapat Maraghi ini juga dikuatkan oleh Ikrimah. Menurut Ikrimah, Luqman al-Hakim adalah seorang nabi, orang yang bijaksana (al-ḥakim). Di dalam kitab Qathr al-Ghayts pun dikatakan bahwa di antara nabi-nabi dan rasul yang telah disebutkan dalam al-Qur'an itu sebenarnya masih banyak nabi yang belum disebutkan namanya sehingga ada kemungkinan Luqman alHakim adalah salah-satu di antara mereka.

\section{b. Menurut Ibnu Abbas}

Luqman al-Hakim adalah seorang hamba sahaya dari Habasyiyah (Ethiopia), kemungkinan besar dia itu ialah Aesopus, karena kata-kata hikmah

17 Ahmad Musthafa al-Maraghi, Tafsir al-Maraghi, terj. Bahrun Abu Bakar, dkk., (Semarang: Karya Toha Putra, 1992), h. 145. 
Aesopus mirip dengan kata-kata bijak Luqman al-Hakim. Aesopus adalah seorang hamba sahaya hitam pula, yang menurut Winkler Prins Encyclopaedie ia hidup pada tahun 550-SM. Menurut Khalid al-Rab'i Luqman adalah seorang hamba sahaya dan tukang kayu dari Habsi.

\section{c. Menurut HAMKA}

Luqman al-Hakim adalah sosok pribadi yang senantiasa mendekatkan hatinya kepada Allah dan merenungkan keagungan alam ciptaan-Nya yang ada di sekelilingnya, sehingga dia mendapat kesan yang mendalam, demikian juga renungannya terhadap kehidupan ini, sehingga pada akhirnya terbukalah baginya rahasia hidup (hikmah). ${ }^{18}$

\section{d. Menurut Imam Baidhawi}

Menurut Imam Baidhawi dalam tafsirnya yang berjudul Tafsìr Baidhawy menyebutkan bahwa Luqman adalah salah satu anak dari Azar, saudara sepupu Nabi Ayyub. Ia hidup semasa Nabi Dawud dan pernah menjadi seorang mufti sebelum diutusnya Nabi Dawud sebagai rasul. Lebih lanjut, Baidhawi menyebutkan berdasarkan pendapat mayoritas ulama, Luqman bukanlah seorang nabi melainkan hanya seorang hakim. ${ }^{19}$ Sependapat dengan Baidhawi, Wahbah al-Zuhaili pun mengatakan dalam Tafsìr al-Munīr bahwa Luqman adalah salah-satu anak Azar, saudara sepupu Nabi Ayyub dan ia bertubuh hitam berasal dari Sudan Mesir, hidup sezaman dengan Nabi Dawud as. kemudian ia berguru kepadanya. ${ }^{20}$

Dari beberapa pendapat di atas, mengenai Luqman al-Hakim itu siapa, masing-masing pendapat mempunyai perbedaan maupun kesamaan. Namun, untuk sementara saya menganggap bahwa Luqman al-Hakim yang disebutkan dalam al-Qur'an mempunyai dua makna: pertama, Luqman al-Hakim adalah nama panggilan bagi hamba Allah yang selalu mendekatkan diri kepada-Nya, serta pribadi yang arif bijaksana dalam mengambil suatu keputusan di dalam menghadapi suatu masalah. Hal ini berpijak dari keadaan al-Qur'an itu sendiri yang masih berupa bahasa simbol sehingga memerlukan adanya penafsiran dan

18 Hamka, Tafsir al-Azhar..., h. 142.

19 Baidhawi, Tafsir Baidhawy, 1996, h. 346.

${ }^{20}$ Wahbah al-Zuhaili, Tafsir al-Munïr, Juz XXI, (Beirut: Darul Fikri, 1991), h. 91. 
penerjemahan; kedua, Luqman al-Hakim ialah kisah dari seseorang yang berhasil mendidik anak-anaknya yang kemudian namanya diabadikan dalam al-Qur'an.

\section{Nilai-nilai Pendidikan Surat Luqman}

Nilai-nilai pendidikan Islam yang terkandung dalam al-Qur'an surat Luqman ayat 12-19 menurut hemat penulis terdiri dari tiga pokok pendidikan, yaitu; pendidikan aqidah, pendidikan syariah dan pendidikan akhlak.

\section{a. Pendidikan Aqidah}

Pendidikan aqidah adalah pendidikan yang berusaha mengenalkan, menanamkan serta mengantarkan anak akan nilai-nilai kepercayaan terhadap rukun-rukun iman dan lain sejenisnya. Dari nasihat-nasihat Luqman terhadap anaknya, termasuk dalam kategori pendidikan aqidah terdapat pada ayat 12-19 dari surat Luqman yaitu; larangan menyekutukan Allah dan meyakini adanya tempat kembali.

\section{1) Larangan Menyekutukan Allah}

Penanaman rasa keimanan yang murni sejak anak mulai diusia tingkat Taman Kanak-kanak dan Sekolah Dasar sangatlah penting, sebab naluri anakanak pada usia ini telah mampu menerima pendidikan keimanan.

Luqman al-Hakim sendiri pun memprioritaskan pendidikan tauhid kepada anaknya. Terbukti pendidikan tauhid telah mendapatkan tempat pertama dari wasiatnya dalam surat Luqman, yakni pada ayat ke-12 dan ke-13. Setelah pada ayat ke-12 diperintahkan bersyukur kepada Allah, yakni Dzat yang wajib ada, maka menurut ayat ke-13 Luqman berkata, "Hai anakku, janganlah kamu mempersekutukan Allah, sesungguhnya mempersekutukan Allah adalah benar-benar kezaliman yang besar." Syirik dinamakan perbuatan yang zalim, karena perbuatan syirik itu berarti meletakkan sesuatu bukan pada tempatnya, maka ia termasuk dalam kategori dosa besar. Perbuatan tersebut juga berarti menyamakan kedudukan Tuhan dengan makhluk-Nya. ${ }^{21}$ Walaupun pada hakikatnya keimanan atau kekufuran itu tidak mempengaruhi kebesaran-Nya sebagai Raja dari segala Raja, akan tetapi demi kebahagian makhluk-makhluk-Nya, Dia pun memerintahkan agar makhluk-

${ }^{21}$ Ahmad Musthafa al-Maraghi, Tafsir al-Maraghi, h. 153. 
makhluk-Nya supaya beriman kepada-Nya. Inilah salah satu sifat raḥmān dan rahìm Allah SWT, sebagaimana tertuang dalam firman-Nya:

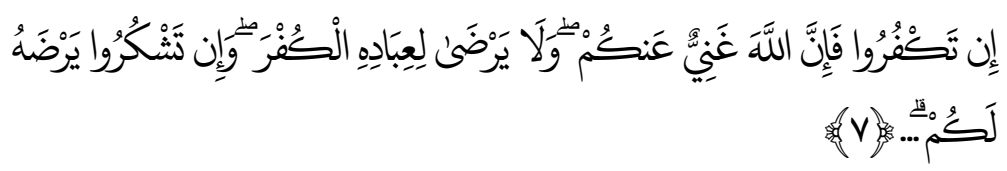

"Jika kamu kafir, maka sesungguhnya Allah tidak memerlukan (iman) mu dan Dia tidak meridhai kekafiran bagi hamba-Nya; dan jika kamu bersyukur, niscaya Dia meridhai bagimu kesyukuranmu itu ...." 22

Bila direnungkan lebih mendalam ada baiknya setiap individu belajar bersyukur atas berbagai nikmat yang diperolehnya, karena dengan bersyukur diharapkan mereka bisa meminimalisir bahkan bisa terhindar dari perbuatan syirik. Hal ini diperjelas oleh Imam Qurthubi dalam tafsirnya Tafsīr al-Qurthuby bahwa hakikat bersyukur adalah menaati segala perintah dan menjauhi segala larangan-Nya..23 Dengan demikian, andaikata manusia mampu mensyukuri nikmat dengan sungguh-sungguh secara otomatis mereka tidak akan terperangkap dari perbuatan syirik.

Hal ini pun terlihat pada ayat ke-13 di atas, huruf 'ațf wawu pada awal ayat wa-idzqāla luqmānu... lā tushrik billāh itu ma'tuf-nya kembali pada ayat anishkur lillāh. Ini mengandung pemahaman bahwa sesungguhnya perbuatan syirik itu tidak akan dilakukan oleh orang-orang yang pandai bersyukur. Apalagi dengan adanya seruan Allah SWT yang mencegah segala bentuk tindakan syirik, maka sebagai makhluk yang berakal sudah semestinya ia tidak melakukan tindakan tersebut.

Larangan perbuatan syirik ini pun terlihat dengan jelas secara redaksional pada ayat ke-13 di atas. Huruf lā nahy pada kata lā tushrik billāh yang dijadikan Tuhan sebagai bentuk pencegahan terhadap tindakan syirik dalam ilmu usul fiqih termasuk memberikan makna li tahdìd, artinya bentuk larangan secara keras. ${ }^{24}$ Dengan demikian, dapat dipahami bahwa Allah SWT benarbenar mencegah segala bentuk tindakan syirik dan mengatagorikan dosa syirik sebagai perbuatan aniaya yang amat besar (laẓulmun 'aẓim). Perlu

\footnotetext{
${ }^{22}$ QS. al-Zumar [39]: 7.

${ }^{23}$ Qurthubi, Tafsir al-Qurthuby,1992, h. 301.

${ }^{24}$ Abdul Hamid Hakim, Bayān, Juz III, (Jakarta: Sa'diyah Putra, 1991), h. 31.
} 
diingat, larangan untuk menjauhkan diri dari berbagai tindakan syirik berarti perintah melakukan tindakan yang sebaliknya, yaitu perintah beraqidah secara sungguh-sungguh. Sebagaimana kaidah usul fiqh yang berbunyi: النهي Terjemah bebasnya: "Mencegah untuk meninggalkan sesuatu (syirik) berarti memerintahkan untuk melaksanakan kebalikannya (yaitu beraqidah secara benar)."

Dari penjelasan di atas, jelaslah bahwa syirik merupakan perbuatan keji dan mungkar. Sehingga diharapkan para orang tua mampu memberikan pengarahan dan bimbingan sejak dini. Sebagaimana Luqman al-Hakim mengajarkan kepada anak-anaknya agar tidak terjerumus dalam perbuatan syirik.

\section{b) Meyakini adanya Tempat Kembali}

Penanaman keyakinan adanya balasan di akhirat (tempat kembali) merupakan suatu kepercayaan yang harus ditanamkan sejak anak masih kecil. Sehingga setiap aktivitas yang dilakukan anak akan terkontrol oleh normanorma Islam. Disinyalir pengawasan alat negara ataupun pengawasan manusia lainnya tidak mampu untuk mencegah perilaku yang menyimpang. Oleh karena itulah penanaman keimanan terhadap adanya pengawasan dari Yang Maha Melihat kepada anak sangat dibutuhkan, agar luruslah jalan anak menuju yang diridhai-Nya.

Dalam Tafsìr al-Qur'ān li al-Qur'ān dijelaskan bahwa kata ilayya '-mașīr pada ayat ke-14 di atas, mengandung isyarat sesungguhnya Allah SWT adalah Tuhan yang mengetahui segala urusan manusia. Hubungan antara anak dan kedua orang tuanya adalah sebatas perantara zahiriyyah wujudnya seorang anak di dunia, sedangakan mengenai urusan aqidah mereka tidak berhak menyesatkan anak-anaknya. Oleh karena itu sebagai seorang anak hendaknya senantiasa berbuat baik kepada kedua orang tua, sekaligus sebagai ungkapan terima kasih kepada keduanya.

Di sisi lain, ada yang menafsirkan kata ilayya 'l-mașîr sebagai bentuk penegasan seruan taat kepada-Nya dan kepada kedua orang tua. Segala kebaikan dan keburukan yang dilakukan manusia baik kepada Allah SWT maupun kepada kedua orang tuanya akan dibalas di hari pembalasan tergantung amal yang diperbuat. 25

${ }^{25}$ Wahbah al-Zuhaili, Tafsir al-Munīr..., h. 147. 
Menurut Zakiah Darajat dengan adanya kesadaran akan pengawasan Allah yang tumbuh dan berkembang dalam pribadi anak, maka akan masuklah unsur pengendali terkuat di dalam kepribadian anak. Dengan demikian, kesadaran yang tinggi atas pengawasan-Nya akan berdampak positif terhadap jiwa psikologis anak dalam menjalani samudera kehidupan dikemudian hari, terutama dalam menentukan sesuatu yang hak dan yang batil. ${ }^{26}$

Terkait dengan hal ini, Luqman al-Hakim pun berwasiat kepada anakanaknya tentang adanya balasan akhirat, yakni dalam akhir ayat ke-15. Artinya: "Kemudian hanyalah kepada-Ku kembali kalian, maka Kuberitakan apa yang kalian kerjakan." 27 Menurut al-Maraghi28 ayat tersebut di atas menjelaskan adanya balasan terhadap segala amal perbuatan manusia pada umumnya. Khususnya balasan atas rasa syukur kita kepada-Nya terhadap segala nikmat dan rasa penghormatan kita kepada kedua orang tua.

Mengingat begitu pentingnya penanaman keyakinan terhadap adanya pertanggung jawaban di hari akhir, maka diharapkan sebagai orang tua yang sadar akan tanggung jawabnya harus memberikan pengarahan dan bimbingan sebagaimana Luqman al-Hakim mendidik anak-anaknya. Perlu diingat bahwa penanaman keyakinan adanya hari pembalasan pada pribadi anak akan dapat bermanfaat sebagai salah satu upaya pengendali terhadap diri pribadi seorang anak.

\section{b. Pendidikan Syariah}

Pendidikan syariah adalah pendidikan yang berusaha mengenalkan, menanamkan serta menghayatkan anak terhadap nilai-nilai peraturan Allah tentang tata cara pengaturan perilaku hidup manusia, baik yang berhubungan secara vertikal dengan Allah yang disebut ibadah, maupun berhubungan secara horizontal dengan makhluk-Nya, yang disebut hubungan muamalah. Dalam ibadah, bentuk peribadatan yang bersifat khusus pelaksanaanya telah dicontohkan oleh Nabi Muhammad SAW, seperti shalat, puasa dan zakat. Oleh karena itu, kita harus mengikuti apa yang dicontohkan Nabi. ${ }^{29}$

26 Zakiah Darajat, Ilmu Jiwa Agama, (Jakarta: Bulan Bintang, 1970), h. 63.

27 QS. Luqman [31]: 15.

${ }^{28}$ Ahmad Musthafa al-Maraghi, Tafsir al-Maraghi... h. 54. 103.

${ }^{29}$ Nurdin, Muslim dan Ishak Abdullah, Moral dan Kognisi Islam, (Bandung: Alfabeta, 1993), h. 
Sedangkan dalam muamalah, bentuk peribadatan yang bersifat umum, pelaksanaannya tidak seluruhnya dicontohkan langsung oleh nabi, namun beliau hanya meletakkan prinsip-prinsip dasar, sedangkan pengembangannya diserahkan kepada kemampuan dan daya jangkau umat. Seperti ekonomi, bisnis, jual beli, perbankan, perkawinan, pewarisan, pidana, tata negara dan sebagainya.

\section{1) Perintah Mendirikan Shalat}

Shalat adalah salah satu bentuk sarana ritual yang menandakan ketundukan seorang hamba kepada Tuhannya. Shalat juga bisa diartikan sebagai bentuk konkret manusia mensyukuri segala nikmat-Nya. Dalam hal ini, Luqman al-Hakim sebagai pribadi yang bertanggung jawab memerintahkan kepada anak-anaknya untuk mendirikan shalat. Perintah ini secara redaksional nampak sangat jelas betapa Luqman mendidik anak-anaknya dengan menggunakan motode yang sangat humanis, yaitu model bertahap (tadrīj). Mulai dari larangan berbuat syirik, menanamkan keyakinan adanya tempat kembali sebagai balasan atas berbagai amal manusia, dan perintah mendirikan shalat lima waktu. Sebagaimana Nabi Muhammad memberi tuntunan dalam haditsnya, "Perintahkanlah anak-anakmu shalat ketika berumur tujuh tahun, dan pukullah mereka karena meninggalkan shalat jika telah berumur sepuluh tahun, dan pisahkan anak laki-laki dari anak perempuan dalam tempat tidur mereka." (HR. Abu Dawud, al-Turmudzi dan al-Hakim). ${ }^{30}$

Tuntunan para nabi yang telah diimplementasikan oleh Luqman alHakim baik secara metodologis maupun aplikatif di lapangan hendaknya bisa dicontoh dan dilaksanakan oleh para orang tua ataupun para pendidik. Sehingga mutiara hikmah Luqman yang diabadikan Tuhan dalam al-Qur'an bisa membumi dan berakar, bukan hanya sekedar i'tibār tanpa adanya pengamalan. Apalagi diperparah dengan adanya pengaruh globalisasi media elektronik; televisi, internet, mass media, video game dan sejenisnya seakan telah menggantikan berbagai mutiara hikmah dari orang-orang shalih.

Menurut Mushthafa al-Maraghi ${ }^{31}$ dalam kitab tafsirnya yang berjudul Tafsir al-Maraghi dijelaskan, perintah mendirikan shalat yang terdapat dalam surat Luqman ayat ke-17 mempunyai arti bahwa perintah untuk menjalan-

${ }^{30}$ Hasan Langulung, Beberapa Pemikiran Pendidikan Islam, h. 373.

${ }^{31}$ Ahmad Musthafa al-Maraghi, Tafsir al-Maraghi... h. 158. 
kan shalat dengan sempurna sesuai dengan cara yang diridhainya. Karena di dalam shalat itu terkandung ridha Tuhan, sebab orang yang mengerjakannya berarti menghadap dan tunduk kepada-Nya. Dan di dalam shalat terkandung pula hikmah lainnya, yaitu dapat mencegah orang yang bersangkutan dari perbuatan keji dan mungkar. Maka apabila seseorang menunaikan hal itu dengan sempurna, niscaya bersilah jiwanya dan berserah diri kepada-Nya, baik dalam keadaan suka maupun duka.

Namun demikian, persoalan yang memprihatinkan dari peradaban saat ini adalah hilangnya nilai-nilai shalat dari sendi-sendi kehidupan ummat Islam. Seakan shalat hanyalah sekedar ritualitas dan tradisi tanpa makna, hampa dari esensi ontologisnya, tercerabut dari tujuannya. Padahal, secara tegas dalam doa iftitah kaum Muslim mengikrarkannya minimal lima kali dalam sehari: inna șalātī wanusukī wa mahyāyya wamamātī lillāhi rabbi 'l'àlaminn, yang artinya: "Sesungguhnya shalatku, ibadahku, hidup dan matiku hanyalah untuk Allah SWT, Tuhan seisi alam."

Berpijak pada Tafsir al-Maraghi dalam surat Luqman ayat ke-17 di atas, dimungkinkan kaum Muslim sampai saat ini belum mampu melaksanakan shalat dengan sempurna. Hal ini terbukti dari berbagai kasus kriminalitas yang terjadi di Indonesia mulai perampokan, pembunuhan, tindakan Korupsi Kolusi Nepotisme (KKN), tawuran, perjudian, pelecehan seksual, narkoba, dekadensi moral dan lain sejenisnya, kebanyakan dilakukan oleh "ummat Islam." Padahal, apabila kaum Muslimin mampu dan mau merenungkan dari setiap gerakan dan bacaan-bacaan shalat yang dilakukannya, manfaatnya sangatlah luar biasa, terlebih dalam membentuk kepribadian Islami. Sebagai contoh yang sangat sederhana misalnya, prosesi pelaksanaan sujud. Di setiap shalat acapkali seorang Muslim melaksanakan gerakan sujud, dengan cara meletakkan (menundukkan) wajahnya ke bumi (tempat sujud), sembari diikuti dengan meletakkan kedelapan anggota tubuhnya di atas tempat sujud; yaitu menempelkan kening, hidung, kedua tangan, kedua lutut, dan jari-jari kedua kaki. Kemudian diiringi dengan bacaan subḥānaka rabbiya I-a'lā wa bihamdihi, arti bebasnya: "Mahasuci Tuhan yang menguasai 'arsy (tempat yang gaib) dengan kesuciannya."

Hal ini mengandung isyarat, bahwa manusia adalah makhluk yang lemah, kedudukannya di sisi Tuhan adalah sama, tidak dibedakan oleh warna kulit, ras, suku, golongan, pangkat, kekayaan, kemewahan dan lain sebagainya. Kedelapan anggota tubuh yang biasanya digunakan sebagai simbol keangkuhan manusia. Pada saat melaksanakan prosesi sujud dipaksa "tunduk" 
kepada Yang Maha berhak. Karena pada hakikatnya harkat dan martabat, kekayaan dan kemegahan manusia di dunia merupakan kamuflase yang semu dan sementara. Sedangkan yang membedakan manusia satu dengan manusia lainnya adalah ketakwaannya di sisi-Nya.

Dengan demikian, merupakan suatu keniscayaan apabila para orang tua maupun para pendidik mulai mengajarkan nilai-nilai dari pelaksanaan shalat kepada anak-anaknya. Baik mengajarkan nilai-nilai yang terkandung dalam bacaan shalat, maupun nilai-nilai dari gerakannya. Minimal memberi pemahaman bahwa shalat bukanlah sekedar ritualitas tanpa makna, melainkan ritualitas bermakna yang dapat mengantarkan anak-anak menjadi pribadi yang sukses, baik di dunia maupun di akhirat. Terlebih apabila penanaman dan pendidikan yang demikian ini diajarkan para orang tua pada saat anakanak masih berumur 0-12 tahun, niscaya mereka akan senantiasa mengingat, mengamalkan, dan menjadikan batu pijakan nasihat-nasihatnya tersebut dalam menjalani kehidupan sehari-hari. ${ }^{32}$

\section{2) Perintah Amar Ma'rūf Nahy Munkar}

Setelah menyuruh anak-anaknya untuk mendidirikan shalat, Luqman alHakim pun pada ayat ke-17 melanjutkan nasihatnya, agar anak-anaknya supaya berbuat kebaikan dan mencegah kemungkaran. Al-Zuhaili33 menafsirkan kalimat wa'mur bi 'l-ma'rüf pada ayat ke-17 ini sebagai ajakan Luqman al-Hakim kepada dirinya sendiri maupun orang lain (anak-anaknya) untuk berbuat kebajikan, seperti budi pekerti yang baik, melakukan pekerjaan yang mulia, membersihkan jiwa dari keburukan. Sedangkan kalimat wanhā 'an al-munkar sebagai ajakannya untuk mencegah kemaksiatan, kejelekan dan kemungkaran baik kepada dirinya sendiri maupun kepada orang lain yang bisa menyebabkan kemurkaan Allah.

Lain halnya dengan al-Zuhaili, al-Maraghi ${ }^{34}$ menafsirkan kalimat wa'mur bi 'l-ma'rüf dalam surat Luqman ayat ke-17 ini sebagai seruan Luqman alHakim agar orang lain (anak-anaknya) supaya mau membersihkan dirinya sesuai dengan kemampuannya. Maksudnya supaya jiwanya menjadi suci dan demi untuk mencapai keuntungan. Sedangkan kalimat wanhā 'an al-munkar

\footnotetext{
32 Sumadi Suryabrata, Psikologi Pendidikan, (Jakarta: Rajawali Press, 1995), h. 200.

33 Wahbah al-Zuhaili, Tafsīr al-Munīr..., h.150.

${ }^{34}$ Ahmad Musthafa al-Maraghi, Tafsir al-Maraghi... , h. 159.
} 
ditafsirkan sebagai seruan agar manusia mau mencegah perbuatan durhaka kepada Allah SWT, dan dari mengerjakan larangan-larangan-Nya yang membinasakan pelakunya serta menjerumuskannya ke dalam azab neraka yang apinya menyala-nyala, yaitu neraka jahanam dan seburuk-buruk tempat kembali adalah neraka jahanam.

Walupun sepintas lalu kedua mufassir di atas, berbeda pendapat dalam memberi penafsiran tentang makna amar ma'rüf nahy munkar. Namun, pada prinsipnya keduanya sependapat bahwa perintah kebajikan dan mencegah berbagai kejelekan merupakan perintah Luqman al-Hakim kepada anakanaknya pada khususnya dan umat manusia pada umumnya. Dengan demikian, para orang tua maupun para pendidik hendaknya mau mengikuti jejak Luqman al-Hakim yang tidak pernah bosan menyerukan kebaikan dan mencegah segala bentuk kemungkaran di mana pun ia berada. Tentunya sesuai dengan kemampuan dan kapasitasnya masing-masing.

\section{c. Pendidikan Ahklak}

Pendidikan akhlak adalah pendidikan yang berusaha mengenalkan, menanamkan serta menghayatkan anak akan adanya sistem nilai yang mengatur pola, sikap dan tindakan manusia atas isi bumi. Pola sikap dan tindakan yang dimaksud mencakup pola-pola hubungan dengan Allah, sesama manusia (termasuk dengan dirinya sendiri) dan dengan alam sekitar. ${ }^{35}$ Alih kata, pendidikan akhlak adalah suatu pendidikan yang berusaha mengimplementasikan nilai keimanan seseorang dalam bentuk perilaku. ${ }^{36}$ Sebab pendidikan akhlak adalah bagian yang tidak dapat dipisahkan dari pendidikan agama. Sehingga sesuatu, dianggap baik atau buruk oleh seseorang manakala berdasar pada agama. ${ }^{37}$

Adapun nilai pendidikan akhlak yang terdapat dalam nasihat Luqman pada ayat ke-12-19 adalah mensyukuri nikmat Allah SWT. Atas segala nikmat dan karunia Allah, kita harus bersyukur kepada-Nya. Nikmat Allah meliputi seluruh hidup, sehingga tidak mungkin bagi kita untuk menghitungnya, mulai dari nikmat yang berhubungan dengan jasmani, rohani, materi dan non

\footnotetext{
${ }^{35}$ Nurdin, Muslim dan Ishak Abdullah, Moral dan Kognisi Islam, h. 205.

${ }^{36}$ Zakiah Darajat, Ilmu Jiwa Agama, h. 58.

${ }^{37}$ Hasan Langulung, Beberapa Pemikiran Pendidikan Islam, h. 373.
} 
materi dengan berbagai ragam. Sebagaimana berfirman-Nya dalam al-Qur'an yang berbunyi:

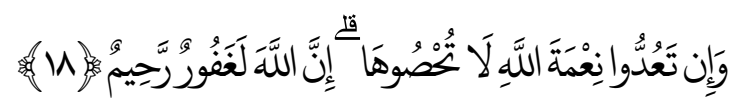

"Jika kamu hitung nikmat Allah, niscaya tak dapat kamu menghitungnya. Sesungguhnya Allah Maha Pengampun, lagi Penyanyang." ${ }^{38}$

Ayat tersebut di atas, menurut Wahbah al-Zuhaili ${ }^{39}$ menunjukkan betapa pentingnya mensyukuri nikmat. Lebih lanjut dijelaskan andaikata manusia ingin menghitung dan mengidentifikasi nikmat Allah, niscaya ia tidak akan mampu. Sebab nikmat Allah itu sangat besar jumlahnya (tak terhitung) yang terus menerus ada, sedangkan akal manusia itu sangat terbatas dan lemah.

Nikmat adalah kesenangan, pemberian atau karunia yang diberikan-Nya kepada manusia. Menurut Imam al-Ghazali nikmat berarti setiap kebaikan yang dapat dirasakan kelezatannya dalam kesenangan hidup, tetapi nikmat yang sejati adalah kesenangan hidup di akhirat. Sedangkan syukur menurut Hamka adalah orang yang mampu mempertinggi dirinya sendiri dengan cara mengenang dan menghargai jasa orang lain. ${ }^{40}$ Orang yang paling berjasa terhadap diri kita adalah kedua orang tua. Sehingga Tuhan pun memerintahkan setiap manusia agar bersyukur kepada keduanya, dan pada perinsipnya yang maha berjasa adalah Allah SWT. Dalam hal ini, Imam al-Qusyairi mengutip dari Syeh Ali Dahaq yang mengatakan bahwa hakikat syukur menurut para ahli ialah pengakuan terhadap nikmat yang diberikan-Nya yang dibuktikan dengan ketundukannya.

Sebagai makhluk yang beradab sudah semestinya manusia senantiasa bersyukur kepada-Nya, akan tetapi pertanyaannya kemudian adalah bagaimana cara bersyukur yang baik itu bisa terlaksana? Namun sebelum hal itu dijelaskan perlu disampaikan terlebih dahulu perbedaan antara kata al-syukr (berterima kasih) dan kata al-hamd (memuji) agar tidak terjadi kesalahan persepsi dalam memahami kedua kata tersebut. Perbedaan kedua kata tersebut pada dasarnya terletak pada tingkat pelaksanaannya. Kata al-hamd

38 QS. al-Nahl [16]: 18.

${ }^{39}$ Wahbah al-Zuhaili, Tafsir al-Munïr..., h. 179.

${ }^{40}$ Hamka, Tafsir al-Azhar..., h. 157. 
itu terkadang hanya diucapkan dalam lisan saja tanpa adanya tindakan, sedangkan kata $a l-s h u k r$ biasanya sudah mencakup syukur secara lisan dan syukur dengan perbuatan.

\section{E. Kesimpulan}

Berdasarkan pembahasan tersebut di atas, ada dua hal yang dapat dijadikan konklusi. Pertama, nilai-nilai pendidikan Islam yang terkandung dalam al-Qur'an surat Luqman ayat 12-19 pada dasarnya meliputi tiga pendidikan fundamental yaitu; pendidikan aqidah, pendidikan syariah, dan pendidikan akhlak.

Kedua, implikasi nilai-nilai pedidikan Islam yang terkandung dalam surat Luqman tersebut, menjadikan pembentukan kepribdian yang Islami sebagai salah satu pilihan guna membentengi anak sedini mungkin dari pengaruh lingkungan yang negatif. Pembentukan kepribadian anak pada prinsipnya merupakan proses yang berkelanjutan.

Proses tersebut akan lebih baik dan berhasil manakala para orang tua dapat mengkombinasikan dua faktor, yaitu faktor persiapan berfungsi sebagai proses pembentukan kepribadian anak sebelum ia lahir di dunia (prenatal), dan faktor pelaksaan berfungsi sebagai proses pembentukan kepribadian anak setelah ia lahir, melalui pendidikan formal dan pendidikan nonformal. Untuk merealisasikan pembentukan kepribadian yang Islami diperlukan adanya berbagai metode yang dianggap cukup representatif, di antaranya dengan menggunakan metode keteladanan, nasihat, dan pengawasan.[w] 


\section{BIBLIOGRAFI}

Athas, Ali bin Hasan, Nasihat Luqman Hakim untuk Generasi Muda, Yogyakarta: Aditya Media, 1993.

Zuhaili, Wahbah, Tafsir Al-Munir Juz XXI, Beirut: Darul Fikri, 1991.

Darajat, Zakiah, Ilmu Jiwa Agama, Jakarta: Bulan Bintang, 1991.

D. Marimba, Ahmad, Pengantar filsafat Pendidikan Islam, Bandung: al-Ma'arif, 1991.

Fadjar, A. Malik, Reformasi Pendidikan Islam, Jakarta: Fajar Dunia, 1991.

Hurlock, Elizabeth B., Perkembangan Anak jilid II, penerjemah: Med. Meitasari Tjandrasa, Jakarta: Erlangga, 1991.

Hall, Calvin S, Pengantar Kedalaman Ilmu Jiwa Sigmund Freud, penerjemah: S. Tasref, Yogyakarta: Pembangunan, 1991.

HAMKA, Tafsir al-Azhar Juz XXI, Surabaya: Yayasan Latimojong, 1991. Tafsir al-Azhar Juz 1, Jakarta: Pustaka Panjimas, 1991.

Hasan al-Banna, Aqidah Islam, Bandung: al-Ma'arif, 1991.

Hamka (Haji Abdul Malik Abdul Karim Amrullah), Tafsir Al-Azhar Juz 1, Jakarta: Pustaka Panjimas, 1991.

Karim Khatib, Abdul, Tafsirul Qur'an Lil Qur'an, Beirut: Darul Fikri, 1991. Prinsip-prinsip dan Metode Pendidikan Islam, Bandung: Diponegoro, 1991.

Langgulung, Hasan, Manusia dan Pendidikan Suatu Analisa Psikologi dan Pendidikan, Jakarta: Al-Husna Zikra, 1991. Beberapa Pemikiran Pendidikan Islam, Bandung: al-Ma'arif, 1980.

Pendidikan Islam Menghadapi Abad ke-21, Jakarta: Pustaka al-Husna, 1988.

Ma'arif, A Syafi'i, Pendidikan Islam di Indonesia, Antara Cita dan Fakta, Yogyakarta: Tiara Wacana, 1991.

Musthafa al-Maraghi, Ahmad, Tafsir al-Maraghi, penerjemah: Bahrun Abu Bakar, dkk., Semarang: Karya Toha Putra, 1992.

Mulyana, Rohmat, Mengartikulasikan Pendidikan Nilai, Bandung: Alfabeta, 2004.

Najati, Usman, Al-Qur'an dan Ilmu Jiwa, Bandung: Pustaka, 1997. 
Nurdin, Muslim dan Ishak Abdullah, Moral dan Kognisi Islam, Bandung: Alfabeta, 1993.

Quthb, Muhammad, Sistem Pendidikan Islam, terj. Salman Harun, Bandung: alMa'arif, 1988.

Pendidikan Islam Keluarga dan Sekolah, Bandung: Rosdakarya Offset, 1995.

Sumadi Suryabrata, Psikologi Pendidikan, Jakarta: Rajawali Press, 1995.

Tafsir, Ahmad, Ilmu Pendidikan dalam Perspektif Islam, Bandung: Remaja Rosdakarya, 2001.

Zuhairi, dkk., Sejarah Pendidikan Islam, Jakarta: Depag, 1996. 